\title{
PENERAPAN METODE CARD SORT UNTUK MENINGKATKAN MOTIVASI BELAJAR FIQH SISWA MTS NABIL HUSEIN SAMARINDA
}

\author{
Herwin \\ UIN Sultan Aji Muhammad Idris \\ herwin123@gmail.com \\ Said Husin \\ UIN Sultan Aji Muhammad Idris \\ abisaidhusin@gmail.com \\ Indriana Rahmawati \\ UIN Sultan Aji Muhammad Idris \\ indria.rahma@gmail.com
}

\begin{abstract}
Abstrak
Pembelajaran dengan menggunkan metode yang menyenangkan diharapkan dapat meningkatkan motivasi belajar siswa. Motivasi memeiliki peran yang penting dalam proses pembelajaran, dengan adanya motivasi belajar siswa diharpkan mampu memahami materi pelajaran dengan baik. Penelitian ini bertujuan untuk mengetahui penerapan metode card sort untuk meningkatkan motivasi belajar figh siswa MTs Nabil Husein Samarinda. Metode penelitan dilakukan dengan menggunkan penedekatan kialitatif, sumber data penelitian adalah kepala sekolah, guru Fiqh dan siswa MTs Nabil Husein Samarinda. Teknik pengumpuan dilakukan dengan cara wawancara dan dokumentasi. Keabsahan data diuji dengan menggunakan tekknik triangulasi. Hasil dari penelitian adalah sebagai berikut, 1) Pemilihan metode pembelajaran aktif dan menyenangkan dapat meningkatkan motivasi belajar siswa, 2) Siswa antusias dalam belajar dengan menggunakan metode card sort, 3) Metode card sort dimanfaatkan dengan maksimal di MTs Nabil Husein, 4) Penggunaan metode card sort dapat membantu siswa untuk memahami pelajaran.
\end{abstract}

Kata Kunci: Metode Pembelajaran, Metode Card Sort, Motivasi Belajar

\section{Abstract}

Learning by using a fun method is expected to increase students' learning motivation. Motivation has an important role in the learning process, with the existence of learning motivation students are expected to be able to understand 
the subject matter well. This study aims to determine the application of the card sort method to increase students' motivation to learn figh at MTs Nabil Husein Samarinda. The research method was carried out using a qualitative approach, the sources of research data were school principals, Fiqh teachers, and students of MTs Nabil Husein Samarinda. The collecting technique is done by interview and documentation. The validity of the data was tested by using the triangulation technique. The results of the research are as follows, 1) The selection of active and fun learning methods can increase students' learning motivation, 2) Students are enthusiastic about learning by using the card sort method, 3) The card sort method is maximally utilized at MTs Nabil Husein, 4) The use of the method card sort can help students to understand the lesson.

Keyword: Learning Mothods, Card Sort Methods, Learning Motivation

\section{A. Pendahuluan}

"Motivasi memiliki peran yang sangat penting dalam menentukan hasil belajar". ${ }^{1}$ Motivasi sebagai pendorong dalam melakukan kegiatan pembelajaran menjadi topik utama penelitian pendidikan. Dengan adanya motivasi siswa dapat berperan aktif dalam pembelajaran. Begitu juga sebaliknya, jika siswa tidak memiliki motivasi dalam pembelajaran niscaya pembelajaran yang mereka lakukan tidak akan membuahkan hasil yang memuaskan. Oleh karena itu motivasi siswa dalam belajar harus senantiasa dijaga. Tugas guru selain mengajar juga harus senantiasa memberikan motivasi kepada siswa.

Pemberian motivasi kepada siswa dapat dilakukan dengan berbagai cara, salah satunya adalah dengan mengemas kegiatan pembelajaran semenarik mungkin. Kegiatan belajar tidak terlepas dari kegiatan mengajar, sama halnya dengan belajar, mengajar pun pada hakikatnya merupakan suatu proses, yaitu proses mengatur dan mengorganisasikan lingkungan yang ada di sekitar siswa sehingga dapat menumbuhkan dan mendorong siswa melakukan proses belajar. Pada tahap berikutnya, mengajar adalah proses memberikan bimbingan atau bantuan kepada siswa dalam melakukan proses belajar. ${ }^{2}$ Kegiatan pembelajaran terdiri dari komponen yang saling terkait dan harus dirancang sedemikian rupa agar semua komponen tersebut dapat berperan sebagaimana mestinya. Kebanyakan proses mengajar di sekolah-sekolah mulai dari jenjang terendah sampai jenjang tertinggi menggunakan metode ceramah sebagai metode yang dominan. Padahal, metode ceramah cenderung hanya mengandalkan keaktifan dan kemampuan guru yaitu guru aktif menjelaskan materi pembelajaran di depan kelas, sedangkan siswa lebih banyak hanya duduk terdiam menerima apa yang di sampaikan oleh guru. Oleh karena itu, pembelajaran dengan metode ceramah

\footnotetext{
${ }^{1}$ Esa Nur Wahyuni, Motivasi belajar (DIVA Perss, 2020).

${ }^{2}$ Hamdani, Strategi Belajar Mengajar, (Bandung: CV Pustaka Setia, 2011), h. 17-18.
} 
hanya menempatkan sisiwa pada posisi pasif. Akibatnya proses pembelajaran cenderung membosankan dan siswa tidak dapat mengembangkan keterampilan dan life skill nya.

Penggunaan metode dalam proses pembelajran harus tepat karena untuk membangkitkan motivasi belajar siswa. Pemilihan metode haruslah sesuai dengan materi pelajaran dan situasi ketika proses pembelajran, karena metode tersebut harus efektif dan efesien penggunaanya, karena metode tersebut harus efektif dan efesien penggunaanya, fungsinya untuk mempermudah tercapainya tujuan pembelajaran. ${ }^{3}$ Metode pembelajaran yang efektif adalah penggunaan metode yang menarik. Penggunaan metode yang menarik tentunya akan meningkatkan daya tarik siswa untuk belajar. Salah satu metode yang dapat dimanfaatkan dalam proses belajar mengajar adalah dengan menggunkan sort card. Metode ini merupakan metode yang didesain menggunkan potongan kertas dan dibentuk seperti kartu, kartu-kartu tersebut berisi informasi atau materi pelajaran. Metode Card Sort sangat tepat digunakan dalam pembelajaran dikarenakan salah satu metode yang bisa membangun motivasi siswa dengan cara bermain sambil belajar sehingga siswa cenderung tidak merasa bosan selama proses pembelajaran. ${ }^{4}$

Menurut Siberman, "metode card sort merupakan aktivitas kerjasama yang bisa digunakan untuk mengajarkan konsep, karakteristik, klasifikasi, fakta tentang benda, atau menilai informasi. Gerak fisik yang ada didalamnya dapat membantu menggairahkan siswa merasa penat. ${ }^{5}$ Penerapan metode card sort di MTs Nabil Husein sudah sering diterapkan, akan tetapi pada mata pelajaran fiqh metode card sord digunakan pada materi tertentu saja. Dari hasil observasi awal pada mata pelajaran lain penggunaan metode card sort sangat disenangi oleh siswa.

Kesenangan dan ketertarikan siswa dalam pembelajaran menjadi faktor utama tercapainya tujuan belajar mengajar. Kesenangan dan ketertarikan siswa dalam belajar menjadi motivasi siswa untuk terus semangat dalam mengikuti pembelajaran.

\section{B. Tinjauan Pustaka}

\section{Metode Card Sord}

Metode card sort merupakan suatu strategi pembelajaran berupa potongan-potongan kertas yang dibentuk seperti kartu. Fatah yasin berpendapat bahwa, metode card sort adalah suatu teknik yang digunakan dalam pembelajaran untuk mengajak siswa menemukan konsep dan fakta melalui alat bantu berupa kartu yang berisi klasifikasi materi pembelajaran. ${ }^{6}$ Metode card sort merupakan aktivitas kerjasama yang bisa digunakan untuk

\footnotetext{
3 Muzayyin Arifin, filsafat pendidikan islam, (Jakarta: PT Bumi Askara, 2014), h. 92.

${ }^{4}$ A. Fatah Yasin, "Dimensi-dimensi Pendidikan Islam", (Malang: UIN PRESS, 2010), h. 185

5 Siberman, Strategi Pembelajaran Aktif, (Bandung: Nusa Media, 2006), h. 40.

${ }^{6}$ A. Fatah Yasin, Dimensi-dimensi Pendidikan Islam (Malang: UIN Malang Pers, 2008).
} 
mengajarkan konsep, karakteristik, klasifikasi, fakta tentang benda, atau menilai informasi. ${ }^{7}$

Varian penggunaan metode card sort ada beberapa variasi, menurut Siberman varian ersebut diantaranya adalah:

a. Perhatikan tiap kelompok untuk membuat presentasi pengajaran tentang kategorinya.

b. Pada awal kegiatan, membentuk tim terlebih dahulu. Selanjutnya setiap tim diberikan 1 kotak kartu. Pastika anggota siswa mengocok kartu terlebih dahulu agar ketegori-kategori yang cocok dengan mereka tidak jelas dimana letaknya. Perintahkan tiap tim dapat memperoleh skor untuk jumlah yang dipilih dengan benar. ${ }^{8}$

Zaini mengemukakan langkah-langkah penerapan metode pembelajaran card sort sebagai berikut:

a. Bagikan kertas yang bertuliskan informasi atau kategori tertentu secara acak.

b. Tempelkan kategori utama di papan atau kertas di dinding kelas.

c. Mintalah siswa untuk mencari temannya yang memiliki kertas/ kartu yang berisi kategori yang sama untuk membentuk kelompok dan mendiskusikannya.

d. Mintalah siswa untuk memprsentasikannya. ${ }^{9}$

Penerapan metode card sort menurut Dedi Wahyudi dapat dilakukan dengan langkah-langkah sebagai berikut:

a. Langkah pertama, guru membagikan selembar kartu kepada siswa dan pada kartu tersebut telah dituliskan suatu materi.

b. Langkah kedua, siswa diminta untuk mencari teman (pasangan kartu) yang sesuai dengan kosakata yang ada pada kartunya untuk satu kelompok.

c. Langkah ketiga, siswa akan berkelompok dalam satu kosakata/masalah masing-masing.

d. Langkah keempat, siswa diminta untuk menempelkean dipapan tulis bahasan yang ada dalam kartu tersebut berdasarkan urutan-urutan bahasannya yang depegang kelompok tersebut.

e. Langkah kelima, seorang siswa pemegang kartu dari masing-masing kelompok untuk menjelaskan dan sekaligus mengecek kebenaran urutan.

f. Langkah keenam, bagi siswa yang salah mencari kelompok sesuai bahasan atau materi pelajaran, maka diberi hukuman dengan mencari judul bahasan atau materi yang sesuai dengan kartu yang dipegang.

7 Melvin L. Siberman, Active Learning 101 Cara Belajar Siswa Aktif, Edisi Revisi (Bandung: Nusamedia, 2011).

${ }^{8}$ Melvin L. Siberman.

${ }^{9}$ Hisyam Zaini, Strategi Pembelajaran Aktif di Perguruan Tinggi (Yogyakarta: CTSD, 2002). 
g. Langkah ketujuh, guru memberikan penjelasan/komentar dari permainan tersebut. ${ }^{10}$

Berbagai pandangan di atas dapat disimpulkan bahwa pelaksanaan metode card sort dalam pembelajaran tidak telepas dari upaya meningkatkan keaktifan siswa dalam pembelajaran melalui permainan kartu. Adanya berbagai variasi dari langkang penggunaan metode card sort dapat menjadi alternatif pilihan untuk diterapkan dalam pembelajaran dengan mempertimbangkan relevansi materi, tujuan, dan juga tingkat perkembangan peserta didik.

\section{Motivasi Belajar}

Istilah motivasi berasal dari bahasa latin yaitu movere yang dalam bahasa ingris berarti move adalah kata kerja yang artinya menggerakkan. Motivasi itu sendiri dalam bahasa ingris berarti motivation yaitu sebuah kata benda yang artinya penggerakan. Oleh karena itu ada juga yang menyatakan bahwa "movies dirve at me" motivasilah yang menggerakkan saya, tidak jarang juga dikatakan bahwa seorang siswa gagal dalam mata pelajaran tertentu karena kurangnya motivasi. ${ }^{11}$ Menurut Sobry Sutikono istilah motivasi dapat diartikan sebagai penggerak yang ada di dalam diri seseorang untuk melakukan aktivitas-aktvitas tertentu demi tercapainya suatu tujuan. ${ }^{12}$

Menurut Oemar Hamlik, motivasi adalah suatu perubahan energy di dalam pribadi seseorang yang ditandai dengan timbulnya afektif dan reaksi untuk mencapai tujuan. Dari pengertian tersebut, mengandung tiga unsur dari motivasi:

a. Motivasi dimulai dari adanya perubahan energy dalam pribadi

b. Motivasi ditandai dengan timbulnya perasaan

c. Motivasi ditandai oleh reaksi-reaksi untuk mencapai tujuan. ${ }^{13}$

Dengan ketiga elemen di atas, maka dapat dikatakan bahwa motivasi akan menyebabkan terjadinya suatu perubahan energy yang ada pada diri manusia, sehingga akan bergayut dengan persoalan gejala kejiwaan, perasaan dan juga emosi, untuk kemudian bertindak atau melakukan sesuatu. Semua ini di dodorng karena adanya tujuan, kebutuhan atau keinginan. ${ }^{14}$ Dalam kegiatan belajar, motivasi dapat dikatakan sebagai keseluruhan daya penggerak di dalam diri siswa yang menimbulkan kegiatan belajar, yang menjamin kelangsungan dari kegiatan belajar dan yang memberikan arah pada kegiata belajar, sehingga tujuan yang dikehendaki oleh subjek belajar itu dapat tercapai. Motivasi sangat diperlukan di dalam kegiatan belajar sebab seorang yang tidak mempunyai motivasi dalam belajar, tidak mungkin melakukan aktivitas belajar.

\footnotetext{
${ }^{10}$ Dedi Wahyudi, Inovasi Pembelajaran (Jakarta: Rajawali Pers, t.t.).

${ }^{11}$ Richard I. Arends, Learning To Teach, (Yokyakarta:Pustaka Belajar, 2008), hlm, 142.

12 Sobry Sutikno, Belajar dan Pembelajaran, (Lombok: Holistica, 2013), hlm 69.

${ }^{13}$ Oemar Hamlik, Psikologi Belajar Mengajar, (Bandung: Sinar Baru Algensindo, 2012), h. 173174 .

${ }^{14}$ Sadirman, Interaksi dan Motivasi Belajar Mengajar, (Jakarta: PT Raja Grafindo Persada, 2011), 
Motivasi memiliki ciri-ciri, adapun ciri-ciri motivasi menurut sudirman adalah sebagai berikut:
a. Tekun menghadapi tugas
b. Ulet menghadapi kesulitan belajar
c. Menunjukan minat terhadap pembelajaran
d. Lebih senang kerja mandiri
e. Dapat memperhankan pendapatnya (kalau sudah yakin akan sesuatu)
f. Tidak mudah melepas hal yang diyakini itu
g. Senang mencari dan memecahkan masalah soal-soal. ${ }^{15}$

Dari uraian diatas, dapat disimpulkan bahwa siswa memiliki motivasi tinggi dapat dilihat dari beberapa ciri-ciri tersebut, diantaranya siswa tekun menghadapi tugas, siswa ulet menghadapi kesulitan belajar, siswa senang terhadap mata pelajaran, siswa memperhatikan saat guru menerangkan materi, siswa berani mempertahankan pendapat selagi merasa benar dan yakin, siswa tidak mudah menyerah mengerjakan soal-soal latihan yang dianggap sulit.

Macam-macam motivasi yang dilihat dari sudut pandangnya dibagi menjadi dua yaitu.

a. Motivasi intristik

Motivasi intristik adalah motif-motif yang menjadi aktif atau berfungsinya tidak perlu diransang dari luar karena dalam diri setiap individu sudah ada dorongan untuk melkukan sesuatu. Contohnya seseorang yang senang membaca, tidak usah ada yang menyuruh atau mendorongnya, ia sudah rajin untuk mencari buku yang akan dibaca.

b. Motivasi Ekstrinsik

Motivasi ekstrinsik adalah motif-motif yang aktif dan berfungsinya karena adanya perangsang dari luar, contohnya motivasi dari guru orang tua, dan teman-temanya. ${ }^{16}$

Disimpulkan bahwa motivasi dibagi atas dua macam, yaitu motivasi instrinsik dan motivasi ekstrimnsik. Motivasi instrinsik bersumber dari dalam diri seseorang dan motivasi ekstrinsik berasal dari luar diri seseorang. Dalam proses belajar, motivasi dapat tumbuh, hilang atau berubah dikarenakan faktor-faktor yang mempengaruhinya. Beberapa faktor-faktor yang mempengaruhi motivasi belajar, antara lain yaitu sebagai berikut:

a. Cita-cita atau Aspirasi Siswa

Cita-cita sangat berpengaruh terhadap motivasi belajar seseorang karena citacita dapat memperkuat semangatbelajar dan mengarahkan prilaku belajar siswa.

b. Kemampuan siswa

\footnotetext{
${ }^{15}$ Sadirman, Interaksi..., h, 83.

${ }^{16}$ Oemar Hamalik, Kurikulum dan pembelajran, (Jakarta: Bumi Aksara, 2014), h, 112-123
} 
Keinginan siswa diikuti dengan kemampuan dan kecakapan untuk mencapainya. Kemampuan akan memperkuat motivasi siswa untuk melakukan tugas perkembangannya.

c. Kondisi siswa

Kondisi siswa yang mempengaruhi motivasi belajar berhubungan dengan kondisi fisik dan kondisi psikologis. Biasanya siswa yang sedang sakit, lapa, lelah atau marah akan mengganggu perhatian belajarnya.

d. Kondisi lingkungan

Kondisi lingkungan adalah lingkungan keluarga, lingkungan sekolah, dan lingkungan masyarakat. Ketiga lingkungan tersebut sangat berpengaruh terhadap motivasi belajar siswa.

e. Unsur-unsur dinamis dalam belajar

Unsur-unsur dlam belajar adalah unsur-unsur yang keberadannya dalam proses belajar tidak stabil, terkadang kuat, terkadang lemah, dan bahkan hilang sama sekali, khususnya kondisi yang sifatnya kondisional.

f. Upaya guru membelajarkan siswa

Guru mempersiapkan diri dalam membelajarkan siswa mulai dari penugasan materi sampai dengan mengevalusai hasil belajar siswa. Upaya tersebut berorientasi pada kepentingan siswa yang diharapkan dapat meningkatkan motivasi belajar. ${ }^{17}$

Kesimpulan dari penjelasan di atas mengenai faktor-faktor yang mempengaruhi belajar adalah cita-cita siswa, kemampuan siswa, kondisi siswa, kondisi lingkungan, unsur dinamis dalam belajar, dan upaya guru membelajarkan siswa.

\section{Metode}

Peelitian dilakukan dengan menggunakan pendekatan kualitatif, adapun sumer data primer penelitian ini ada 3 orang, yaitu kepala sekolah, guru figh, dan siswa MTs Nabil Husein Samarinda. Sumber data skunder peneliti menggunakan silabus, Rencana Pertemuan Pembelajaran (RPP), materi ajar, dan dokumen pendukung lainnya. Pengumpulan data yang dilakukan dalam penelitian ini menggunakan teknik wawancara dan dokumentasi. Data yang sudah diperoleh dianalisis menggunakan tahapan-tahapan yang dikemukakan oleh Miles and Hubermen, yaitu melakukan reduksi data, menyajikan data, verifikasi, dan penarikan kesimpulan. ${ }^{18}$ Untuk uji keabsahan data peneliti menggunakan teknik triangulasi.

\section{Temuan dan Diskusi}

Berdasarkan hasil wawancara yang dilakukan oleh peneliti dengan beberapa pertanyaan, maka didapatkan hasil yaitu:

${ }^{17}$ Syaiful Bahri Djamarah, Psikologi Belajar, (Jakarta: PT Rineka Cipta, 2002), h. 120.

${ }^{18}$ Matthew B. Miles, A. Michael Huberman, dan Johnny Saldana, Qualitative Data Analysis: A Methods Sourcebook (SAGE Publications, 2014). 
1. Pemilihan metode pembelajaran yang dapat meningkatkan motivasi belajar siswa.

Menurut narasumber pertama kepala sekolah MTs Nabil Husein Samarinda yaitu bapak Ahmad Yasin, S.Pd.I., M.Pd beliau mengatakan bahwa:

"dalam memilih metode yang akan digunakan dalam proses pembelajaran itu perlu untuk dipertimbangkan dengan baik, bagaimana sekiranya siswa terlihat aktif, tidak bosan, dan selalu bersemangat mengikuti pelajaran itu artinya adanya motivasi keinginan belajar yang positif. Jika berbicara metode card sort saya rasa mayoritas siswa mengatakan lebih senang jika menggunakan metode card sort dengan permainan kartu yang membuat mereka lebih termotivasi dibandingkan dengan ceramah yang kebanyakan dari mereka bosan dan juga mengantuk. Melihat metode card sort ini dapat meningkatkan motivasi belajar siswa saya sebagai kepala sekolah sangat mendukung jika guru-guru walaupun bukan guru fikih menggunakan metode ini."

Menurut narasumber kedua guru mata pelajaran fikih MTs Nabil Husein Samarinda yaitu bapak Abdul Gafur S.Pd.I., M.Pd beliau mengatakan bahwa:

"berbicara pemilihan metode yang pas untuk meningkatkan motivasi siswa, semua metode bisa meningkatkan motivasi siswanya tapi itu kembali kepada cara penyampaiannya. Saya lebih sering menggunakan metode ceramah dan tanya jawab sebab ini adalah metode yang pas untuk mata pelajaran fiqih, karena fiqih ini berupa uraian yang sangat panjang dan materinya pun banyak. Metode ceramahlah yang menjadi pilihan saya agar semua materi tersampaikan ke anak-anak. Kalau berbicara metode card sort saya juga sesekali menggunakan metode tersebut, kalau melihat siswanya alhamdulillah suka dan aktif karena metode ini kan seperti bermain jadi siswa bersemangat. Pastinya siswa jadi termotivasi dalam belajar

Dari penjelasan kedua narasumber, peneliti dapat menyimpulkan bahwa dalam pemilihan metode pembelajaran yang dapat meningkatkan motivasi belajar siswa, perlu adanya pertimbangan dengan baik dan jika dikarenakan kurangnya motivasi akan membuat siswa tidak akan berhasil dalam pembelajaran dan kurang aktif. Sesuai dengan teori yang menyatakan bahwa "movies dirve at me" motivasilah yang menggerakkan saya, tidak jarang juga dikatakan bahwa seorang siswa gagal dalam mata pelajaran tertentu karena kurangnya motivasi. ${ }^{19}$ Metode card sort adalah salah satu metode yang dapat meningkatkan motivasi belajar siswa walaupun hanya digunakan sesekali saja dan metode ceramah yang menjadi metode yang sangat dominan digunakan sampai saat ini.

${ }^{19}$ Richard I. Arends, Learning To Teach, (Yokyakarta:Pustaka Belajar, 2008), hlm, 142. 
2. Antusias siswa dalam belajar ketika pembelajaran menggunakan metode card sort.

Menurut narasumber pertama kepala sekolah MTs Nabil Husein Samarinda yaitu bapak Ahmad Yasin, S.Pd.I., M.Pd beliau mengatakan bahwa:

"saya lihat siswa-siswa disini atau santri disini senang jika metode card sort atau dengan kartu ini mereka senang dan aktif dikarenakan belajar dengan kartu-kartu dapat mengaktifkan suasana kelas jadi hidup sehingga membuat mereka tidak mengantuk. Guru-guru disini juga saya minta untuk menggunakan metode yang memang membuat siswa aktif dan termotivasi dalam belajar."

Menurut narasumber kedua guru mata pelajaran fikih MTs Nabil Husein Samarinda yaitu bapak Abdul Gafur S.Pd.I., M.Pd beliau mengatakan bahwa:

"menurut mereka pembelajaran dengan metode card sort sangat menyenangkan. Mereka juga berkata bahwa belajar dengan metode seperti ini mereka lebih paham. Hal ini dikarenakan belajar dengan kartu-kartu perhatian mereka tertuju pada penjelasan guru dan belajar jadi mudah dipahami. Materi fiqih itu banyak sekali jadi mereka harus dibuat suka dengan mata pelajaran ini, karena kalau tidak akan membosankan dan mereka akhirnya akan sulit paham.

Menurut narasumber ketiga siswa MTs Nabil Husein Samarinda yaitu Hasan Bisri saudara mengatakan bahwa:

"saya dan teman-teman sangat antusias sekali jika ustadz kami mengajar menggunakan metode card sort, metode ini sangat menyenangkan menurut kami. Terlebih lagi pada saat pembelajaran itu dimulai pada siang hari, kami kebanyakan yang mengantuk termasuk saya sendiri jadi metode dengan menggunakan kartu-kartu itulah solusinya agar kami tidak menggantuk, dan tetap semangat mengikuti pelajaran. Saya juga sering mengatakan ke ustadz kami bahwa materi fiqih ini terlalu banyak dan ada baiknya untuk menggunakan metode ini. Agar kami mudah paham dan waktunya juga cukup sampai materi itu selesai.

Dari penjelasan ketiga narasumber, peneliti dapat menyimpulkan bahwa antusias siswa sangat baik dalam merespon materi pelajaran pada saat guru mengajar menggunakan metode card sort. Mereka menyukai metode ini, menurut mereka metode ini menyenangkan dan bisa lebih paham.

3. Metode - metode yang sering digunakan dalam pembelajaran fikih

Menurut narasumber pertama kepala sekolah MTs Nabil Husein Samarinda yaitu bapak Ahmad Yasin, S.Pd.I., M.Pd beliau mengatakan bahwa:

"disini itu lebih sering menggunakan metode ceramah, tanya jawab, dan diskusi. Yang paling kental digunakan pada mapel fikih itu metode ceramah, jadi metode ceramah itu pasti karena banyak uraian kemudian sudah dipastikan disitu kita padukan dengan metode tanya jawab. Kenapa metode 
ceramah karena fikih itu perlu uraian yang mungkin anak-anak bisa memahami penjelasan-penjelasan ustadnya secara detail kemudian dipadukan metode tanya jawab dengan menyajikan waktu untuk anak-anak agar bisa mengukur kemampuan dan pemahamannya diteori materi fikih sehingga nanti dilakukan post test atau evaluasi melalui praktek."

Menurut narasumber kedua guru mata pelajaran fikih MTs Nabil Husein Samarinda yaitu bapak Abdul Gofur S.Pd.I., M.Pd beliau mengatakan bahwa:

"penggunaan metode pembelajaran yang sering kami gunakan itu pastinya ceramah, dan sangat identik sekali dengan ceramah. Materi fikih itu luas dan lebih baik di sampaikan dengan metode ceramah, agar materimateri bisa tersampaikan secara jelas dan terperinci. Tapi terkadang juga menggunakan metode lain seperti diskusi, praktek, dan metode card sort yang sesekali kita gunakan. Metode card sort ini sebenarnya sangat cocok jika ingin kita terapkan dalam setiap pertemuan tetapi juga dengan tidak melepaskan metode ceramah sepenuhnya. Jadi kalau saya mengajar itu bisa menggunakan beberapa metode dalam setiap pertemuan.

Menurut narasumber ketiga siswa MTs Nabil Husein Samarinda yaitu Hasan Bisri saudara mengatakan bahwa:

"metode yang digunakan ustadz kami biasanya ceramah, tanya jawab, diskusi, praktek. Tapi lebih sering ceramah dan praktek."

Dari penjelasan ketiga narasumber, peneliti dapat menyimpulkan bahwa metode-metode yang sering digunakan pada mata pelajaran fiqih di MTs Nabil Husein adalah metode ceramah, tanya jawab, diskusi, dan praktek.

4. Metode pembelajaran card sort sudah dimanfaatkan secara maksimal atau tidak.

Menurut narasumber pertama kepala sekolah MTs Nabil Husein Samarinda yaitu bapak Ahmad Yasin, S.Pd.I., M.Pd beliau mengatakan bahwa:

"jujur saja kalau saya selama mengajar hanya beberapa kali menggunakan metode ini dalam mengajar. Saya disini mengajar qur'an hadits, tetapi guru-guru yang lain beberapa sudah menggunakan metode card sort termasuk guru fiqih. Kalau berbicara sudah maksimal atau tidaknya digunakan tentu saya tidak, tetapi guru lain pasti sudah menggunakannya secara maksimal terlebih lagi respon anak-anak yang positif terhadap metode pembelajaran ini".

Menurut narasumber kedua guru mata pelajaran fikih MTs Nabil Husein Samarinda yaitu bapak Abdul Gafur S.Pd.I., M.Pd beliau mengatakan bahwa:

"metode card sort ini sebenarnya sangat cocok untuk mata pelajaran yang sangat banyak materinya, termasuk salah satunya mata pelajaran fiqih ini. Namun selama mengajar saya memang jarang menggunakan metode ini, 
saya lebih senang menggunakan metode ceramah, tanya jawab, dan diskusi. Metode ceramah itu yang paling kental saya gunakan dan mungkin juga guru-guru lain. Karena mungkin sudah kebiasaan juga, apalagi disini pondok pesantren, jadi apa-apa disampaikan dengan ceramah. Mereka juga sudah jadi makanan sehari-hari jika ustadz-ustadzahnya ceramah ketika menyampaikan materi. Jadi kalau dibilang sudah maksimal atau belum menggunakan matode card sort, saya bilang belum, tetapi sesekali saya gunakan metode card sort ini.

Dari penjelasan kedua narasumber, peneliti dapat menyimpulkan bahwa metode pembelajaran card sort belum dimanfaatkan secara maksimal, hanya sesekali digunakan dan bahkan sangat jarang digunakan dalam mengajar dan lebih dominan pada metode ceramah.

5. Penggunaan metode card sort dalam mata pelajaran fiqih.

Menurut narasumber pertama kepala sekolah MTs Nabil Husein Samarinda yaitu bapak Ahmad Yasin, S.Pd.I., M.Pd beliau mengatakan bahwa:

"penggunaan metode card sort dalam mata pelajaran fiqih bisa dikatakan cocok atau pas karena jika diperhatikan materi fiqih itu sangat banyak dan semua materi itu penting jadi tidak boleh ada yang dilewatin, semua harus disampaikan kepada anak-anak. Jadi cara guru mensiasatinya dengan menggunakan metode card sort ini. Jadi, saya setuju saja jika guru disini menggunakan metode tersebut, terutama guru fiqih.

Menurut narasumber kedua guru mata pelajaran fikih MTs Nabil Husein Samarinda yaitu bapak Abdul Gofur S.Pd.I., M.Pd beliau mengatakan bahwa:

"menurut saya cocok antara metode ini dengan mata pelajaran fiqih, membantu saya dalam menyelesaikan materi yang terlalu banyak, dengan potongan-potongan kertas yang berisikan materi yang kemudian dibagikan untuk beberapa kelompok. Membuat materi yang banyak bisa dengan mudah terselesaikan sesuai waktu mengajar yang ada". Bisa dibilang metode card sort memang cocok untuk digunakan pada mata pelajaran fiqih. Tapi kalau untuk saya, saya lebih terbiasa menggunakan metode ceramah, tanya jawab dan diskusi. Nah, kalau metode card sort ini sesekali, bisa dibilang jarang saya gunakan.

Dari penjelasan kedua narasumber, peneliti dapat menyimpulkan bahwa penggunaan metode card sort dalam mata pelajaran fiqih cocok dan pas dikarenakan materi fiqih sangat banyak, jadi memerlukan metode seperti ini untuk mengefesienkan waktu agar materi secara keseluruhan dapat tersampaikan.

6. Setelah menggunakan metode card sort siswa lebih memahami pelajaran atau mengalami kesulitan. 
Menurut narasumber ketiga siswa MTs Nabil Husein Samarinda yaitu Hasan Bisri saudara mengatakan bahwa:

"kalau saya sendiri merasa lebih paham jika ustadz kami menggunakan metode card sort permainan kartu itu. Saya rasa temanteman yang lain juga lebih paham, karena kita belajar sambil bermain gitu jadi tidak membosankan dan menyenangkan bagi kami. Tapi ustadz kami jarang menggunakan metode ini, lebih sering menggunakan metode ceramah. Hanya beberapa kali saja menggunakan metode card sort, lebih dominan menjelaskan materi dengan ceramah. Jika ustadz ceramah saya paham juga hanya saja jika terlalu panjang dan lama akan merasa bosan dan kadang mengantuk. Disini kami sekolah dan mondok, kegiatan sekolah saja sampai sore, kembali ke asrama lanjut kegiatan-kegiatan asrama sampai malam. Maka dari itu kami rata-rata sering menggantuk di kelas, jadi kalau materi terlalu panjang dan hanya disampaikan dengan ceramah terasa kurang efektif".

Dari penjelasan narasumber diatas, peneliti dapat menyimpulkan bahwa setelah menggunakan metode card sort siswa lebih memahami pelajaran dibanding metode ceramah. Dengan metode card sort siswa merasa lebih menyenangkan mengikuti pelajaran dan tidak merasa bosan. Sesuai dengan teori berikut "Metode card sort ini dapat membantu menimalisir kelas yang jenuh atau bosan. ${ }^{20}$

Berdasarkan hasil wawancara dan dokumentasi diperoleh data tentang penerapan metode card sort untuk meningkatkan motivasi belajar siswa kelas IX pada mata pelajaran fiqih MTs Nabil Husein Samarinda.

1. Pemilihan metode pembelajaran yang dapat meningkatkan motivasi belajar siswa.

Sebelum seorang guru menggunakan suatu metode pembelajaran seorang guru harus mengetahui terlebih dahulu bagaimana pemilihan metode pembelajaran yang tepat dan dapat meningkatkan motivasi. Yang saya dapatkan dalam pemilihan metode pembelajaran di MTs Nabil Husein Samarinda ialah mereka lebih dominan memilih metode ceramah dan tanya jawab pada saat mengajar. Namun jika bebicara metode Card Sort dalam pemilihan metode untuk meningkatkan motivasi belajar siswa juga cocok saja, hanya saja kurang dipergunakan atau jarang digunakan.

2. Antusias siswa dalam belajar ketika pembelajaran menggunakan metode card sort.

Antusias siswa adalah respon yang mereka berikan ketika guru mengajar pada saat pembelajaran berlangsung, respon positif atau respon negatif yang mereka berikan. Ternyata dari hasil yang peneliti dapatkan siswa MTs Nabil Husein Samarinda sangat antusias ketika guru mereka menggunakan metode Card Sort. Semua beranggapan bahwa metode

\footnotetext{
${ }^{20}$ Ramayulis, Metodologi Pendidikan Agana Islam, Jakarta: Kalam Mulia, 2010, hlm.116.
} 
permainan kartu ini menyenangkan dan bisa lebih mudah paham. Semangat untuk belajar sangat tinggi, mereka terlihat lebih aktif dengan metode tersebut.

3. Metode - metode yang sering digunakan dalam pembelajaran fikih.

Metode pembelajaran adalah suatu proses penyampaian materi pendidikan kepada peserta didik yang dilakukan secara sistematis dan teratur oleh tenaga pengajar atau guru. Setiap metode pembelajaran sebenarnya sama-sama bagus dan baik digunakan pada saat mengajar, hanya saja memiliki keunggulan dan kelemaham masing-masing, sama halnya dengan metode Card Sort. Dari hasil data yang didapatkan peneliti bahwasanya metode-metode yang sering digunakan dalam mata pelajaran fiqih di MTs nabil Husein Samarinda adalah metode ceramah, tanya jawab dan diskusi.

4. Metode pembelajaran card sort sudah dimanfaatkan secara maksimal atau tidak.

Metode Card Sort merupakan suatu strategi pembelajaran berupa potongan-potongan kertas yang dibentuk seperti kartu berisi informasi atau materi pelajaran. ${ }^{21}$ Metode ini mempermudah guru untuk mensiasati jika materi pelajaran fiqih terlalu banyak. Dengan potongan-potongan kertas yang akan dibagi dari beberapa materi, yang kemudian akan menghemat waktu sehingga materi yang banyak dapat tersampaikan semua dengan waktu yang pas. Dari hasil peneliti yang didapatkan bahwa metode Card Sort belum dimanfaatkan secara maksimal pada mata pelajaran fiqih. Hanya sesekali digunakan karena lebih sering menggunakan metode ceramah dan tanya jawab.

5. Penggunaan metode card sort dalam mata pelajaran fiqih.

Penggunaan metode Card Sort dalam mata pelajaran fiqih sangatlah cocok dan pas. Materi fiqih yang sangat penting untuk anak-anak dan juga materi yang sangat banyak itu akan dipermudah untuk menyampaikannya dengan baik kepada anak-anak. Metode ini akan membuat anak-anak lebih paham dan aktif dalam mengikuti pembelajaran. Jika anak aktif dan bersemangat maka materi yang banyak sekalipun akan tersampaikan dengan jelas kepada anak-anak. Sehingga motivasi belajar anak pun meningkat dalam mengikuti pembelajaran. Sesuai dengan teori yang menyatakan "Dengan penerapan metode Card Sort, yang merupakan salah satu metode dalam pembelajaran aktif, diharapkan mampu menambah minat dan motivasi siswa terhadap pembelajaran." ${ }^{22}$

6. Setelah menggunakan metode card sort siswa lebih memahami pelajaran atau mengalami kesulitan.

${ }^{21}$ Ramayulis, Metodologi Pendidikan Agana Islam, Jakarta: Kalam Mulia, 2010, hlm.116.

${ }^{22}$ Warsono dan Hariyanto, Pembelajaran Aktif. Teoeri dan Asemen, (bandung: PT Rosda Karya, 2017), hlm 48. 
Metode Card Sort adalah metode yang menyenangkan karena bisa belajar sambil bermain. Siswa akan aktif dan bersemangat dalam belajar dengan metode ini. Jadi sudah jelas mereka lebih paham dengan menggunakan metode ini. Sesuai dengan hasil yang didapatkan peneliti bahwa anak-anak kelas IX mayoritas lebih paham jika menggunakan metode ini. Sesuai dengan teori yang ada pada salah satu kelebihan metode Card Sort yaitu siswa lebih mudah mengerti tentang materi yang diajarkan. ${ }^{23}$

Teknik triangulasi yang digunakan dalam pengambilan data dengan menggunakan triangulasi teknik dan triangulasi sumber, triangulasi teknik yang terdiri dari wawancara dan dokumentasi. Proses yang dilakukan ialah peneliti melakukan wawancara via telfon dan dokumetasi diambil pada saat peneliti datang langsung kesekolah untuk mengantarkan surat ijin penelitian. Berikut penjelasan triangulasi teknik:

Tahap awal adalah wawancara hal ini peneliti anggap sebagai keadaan dimana informasi diperoleh dengan wawancara atau dengan menanyai informan guna menghasilkan informasi yang mampu menjawab permasalahan di dalam penelitian ini. Pada tahap ini peneliti mewawancarai mengenai penerapan metode Card Sort pada mata pelajaran fiqih dalam meningkatkan motivasi belajar siswa kelas IX MTs Nabil Husein Samarinda yaitu kepada Kepala Sekolah bapak Ahmad Yasin, S.Pd.I., M.Pd, Guru Mata Pelajaran Fiqih bapak Abdul Gofur S.Pd.I., M.Pd, dan siswa yaitu saudara Hasan Bisri.

Tahap kedua adalah dokumentasi yang dimana dokumentasi tersebut antara lain berupa foto, foto profil sekolah, dokumen visi dan misi, dokumen data guru, tenaga pendidik, dan siswa, struktur organisasi dan juga data sarana penunjang.

\section{E. Kesimpulan}

Berdasarkan hasil penelitian yang dilakukan di MTs Nabil Husein Samarinda, maka ditemukan hasil dari penelitian mengenai penerapan metode card sort untuk meningkatkan motivasi belajar siswa kelas IX pada mata pelajaran fiqih bahwasanya metode pembelajaran yang digunakan oleh guru fiqih salah satunya adalah card sort. Metode card sort ini hanya sesekali dan bahkan jarang digunakan oleh guru fiqih dalam mengajar. Di samping penggunaan metode card sort yang jarang digunakan akan tetapi metode inilah yang menjadi salah satu metode yang disenangi oleh siswa kelas IX dan merupakan metode yang diakui dapat meningkatkan motivasi belajar siswa. Rata-rata siswa menyatakan bahwa dengan menggunakan metode ini mereka merasa lebih paham dan lebih semangat dalam belajar sehingga tidak membosankan dan meningkatkan motivasi belajar siswa dalam mengikuti pembelajaran.

\footnotetext{
${ }^{23}$ Silberman, Selvin, Active Learning Cara Belajar Aktif, (Bandung: Nusa Media, 2010)
} 


\section{DAFTAR PUSTAKA}

A. Fatah Yasin. Dimensi-dimensi Pendidikan Islam. Malang: UIN Malang Pers, 2008.

Dedi Wahyudi. Inovasi Pembelajaran. Jakarta: Rajawali Pers, t.t.

Esa Nur Wahyuni, Motivasi belajar DIVA Perss, 2020.

Hamdani, Strategi Belajar Mengajar, Bandung: CV Pustaka Setia, 2011.

Hisyam Zaini. Strategi Pembelajaran Aktif di Perguruan Tinggi. Yogyakarta: CTSD, 2002.

Matthew B. Miles, A. Michael Huberman, dan Johnny Saldana, Qualitative Data Analysis: A Methods Sourcebook, SAGE Publications, 2014.

Melvin L. Siberman. Active Learning 101 Cara Belajar Siswa Aktif. Edisi Revisi. Bandung: Nusamedia, 2011.

Miles, Matthew B., A. Michael Huberman, dan Johnny Saldana. Qualitative Data Analysis: A Methods Sourcebook. SAGE Publications, 2014.

Muzayyin Arifin, filsafat pendidikan islam, Jakarta: PT Bumi Askara, 2014.

Oemar Hamlik, Psikologi Belajar Mengajar, Bandung: Sinar Baru Algensindo, 2012.

Oemar Hamalik, Kurikulum dan pembelajran, Jakarta: Bumi Aksara, 2014.

Richard I. Arends, Learning To Teach, Yokyakarta:Pustaka Belajar, 2008.

Sadirman, Interaksi dan Motivasi Belajar Mengajar, Jakarta: PT Raja Grafindo Persada, 2011.

Silberman, Selvin, Active Learning Cara Belajar Aktif, Bandung: Nusa Media, 2010.

Sobry Sutikno, Belajar dan Pembelajaran, Lombok: Holistica, 2013.

Syaiful Bahri Djamarah, Psikologi Belajar, Jakarta: PT Rineka Cipta, 2002.

Richard I. Arends, Learning To Teach, (Yokyakarta:Pustaka Belajar, 2008.

Ramayulis, Metodologi Pendidikan Agana Islam, Jakarta: Kalam Mulia, 2010.

Ramayulis, Metodologi Pendidikan Agana Islam, Jakarta: Kalam Mulia, 2010.

Wahyuni, Esa Nur. Motivasi belajar. DIVA Perss, 2020. 
Warsono dan Hariyanto, Pembelajaran Aktif. Teoeri dan Asemen, Bandung: PT Rosda Karya, 2017. 